\title{
Analytical Method Development and Validation for the Quantification of Acetone and Isopropyl Alcohol in the Tartaric Acid Base Pellets of Dipyridamole Modified Release Capsules by Using Headspace Gas Chromatographic Technique
}

\author{
Sriram Valavala $\mathbb{D}^{\mathbb{D}},{ }^{1}$ Nareshvarma Seelam $\mathbb{D}^{1},{ }^{1}$ Subbaiah Tondepu $\mathbb{D}^{1},{ }^{1}$ \\ V. Shanmukha Kumar Jagarlapudi $\mathbb{D}^{1},{ }^{1}$ and Vivekanandan Sundarmurthy $\mathbb{D}^{2}$ \\ ${ }^{1}$ Department of Chemistry, K L University, Green Fields, Vaddeswaram, Guntur 522502, Andhra Pradesh, India \\ ${ }^{2}$ Research and Development, Bluefish Pharmaceuticals Private Limited, Bangalore 560115, Karnataka, India
}

Correspondence should be addressed to Subbaiah Tondepu; tsubbaiah@yahoo.com

Received 20 September 2017; Accepted 12 November 2017; Published 1 March 2018

Academic Editor: Guido Crisponi

Copyright (c) 2018 Sriram Valavala et al. This is an open access article distributed under the Creative Commons Attribution License, which permits unrestricted use, distribution, and reproduction in any medium, provided the original work is properly cited.

\begin{abstract}
A simple, sensitive, accurate, robust headspace gas chromatographic method was developed for the quantitative determination of acetone and isopropyl alcohol in tartaric acid-based pellets of dipyridamole modified release capsules. The residual solvents acetone and isopropyl alcohol were used in the manufacturing process of the tartaric acid-based pellets of dipyridamole modified release capsules by considering the solubility of the dipyridamole and excipients in the different manufacturing stages. The method was developed and optimized by using fused silica DB-624 $(30 \mathrm{~m} \times 0.32 \mathrm{~mm} \times 1.8 \mu \mathrm{m})$ column with the flame ionization detector. The method validation was carried out with regard to the guidelines for validation of analytical procedures Q2 demanded by the International Council for Harmonisation of Technical Requirements for Pharmaceuticals for Human Use (ICH). All the validation characteristics were meeting the acceptance criteria. Hence, the developed and validated method can be applied for the intended routine analysis.
\end{abstract}

\section{Introduction}

Dipyridamole (2,6-bis-(diethanolamino)-4,8-dipiperidino(5,4-d)-pyrimidine) displays antithrombotic and antiaggregatory activity. The dipyridamole (Figure 1) is used in combination with "blood thinners" such as warfarin to avoid clot formation after heart valve replacements. Clots are a serious complication that can cause strokes, heart attacks, or blocked blood vessels in the lungs (pulmonary embolisms). Dipyridamole is an antiplatelet drug. Dipyridamole is an odourless yellow crystalline powder, having a bitter taste.

Dipyridamole exhibits a relatively short biological halflife of less than one hour. Therefore, extended release formulations of dipyridamole, which provide a continual administration of active ingredient over time, are preferred. Dipyridamole is soluble in acidic mediums with a $\mathrm{pH}$ below 4 and is practically insoluble in water. Therefore, dipyridamole is readily absorbed in the more acidic regions of the upper gastrointestinal tract, but remains insoluble in the more basic regions of the intestine. To obtain a constant level of dipyridamole in the blood, it is advantageous to formulate a dipyridamole dosage form that releases dipyridamole at a controlled rate and at a defined $\mathrm{pH}$. Acidic components can be coadministered with dipyridamole to maintain a defined $\mathrm{pH}$ level throughout administration. Dipyridamole can also be administered with other active ingredients, such as aspirin. Aspirin (acetylsalicylic acid) is an inhibitory substance which counteracts the aggregation of human blood platelets by inhibiting cyclooxygenase and thereby inhibiting the biosynthesis of the aggregation promoting thromboxane A2 $[1,2]$. The residual solvents present in tartaric acid-based pellets of dipyridamole modified release capsules are classified as class 3 solvents as per the ICH Q3C guidelines. 
<smiles>OCCN(CCO)c1nc(N2CCCCC2)c2nc(N(CCO)CCO)nc(N3CCCCC3)c2n1</smiles>

FIgURE 1: Structure of dipyridamole.

The dipyridamole in tartaric acid-based pellets of dipyridamole modified release $150 \mathrm{mg}$ and $200 \mathrm{mg}$ capsules are available in the market. Each capsule contains dipyridamole $200 \mathrm{mg}$ and $150 \mathrm{mg}$ respective dosage strength. The adults including the elders recommended dose is one capsule twice daily, usually one in the morning and one in the evening preferably with meals. The capsules should be swallowed whole without chewing as per eMC [3].

In the literature survey, quite a few GC method have been reported from the determination of the residual solvents in dipyridamole API [4], few liquid chromatographic methods have been reported for determination of dipyridamole in pharmaceutical preparation [4-6], and few methods have been reported for dipyridamole and its degradation product $[7,8]$. However, several methods were reported for determination of dipyridamole in combination with other drugs [9-12]. Estimation of dipyridamole and its metabolites in human plasma by liquid chromatographicmass spectroscopy and HPLC has been performed [13-15].

The aim of this study is to develop the simple and fast analytical method for estimation of residual solvents in the tartaric acid-based pellets of dipyridamole modified release capsules, and the method can be used for the routine analysis. The developed method was subjected for the analytical validation with respect to specificity, linearity, precision, accuracy, limit of detection (LOD), limit of quantification (LOQ), robustness, and ruggedness as per the ICH guidelines [16].

\section{Materials and Methods}

2.1. Chemicals and Reagents. The GC grade $\mathrm{N}$, $\mathrm{N}$-dimethylsulfoxide, isopropyl alcohol, acetone, HPLC grade water, nitrogen gas, air, and hydrogen. The dipyridamole drug substance, placebo samples of dipyridamole modified release capsules, and samples of dipyridamole modified release capsules were supplied by Bluefish Pharmaceuticals Pvt. Ltd, Bangalore, India.

2.2. Equipment. The analytical method was developed by using the Agilent $7890 \mathrm{~A}$ coupled with G1888 network headspace sampler, analytical balance from Mettler Toledo, micropipette from Eppendorf, headspace crimp vials, and suitable glass apparatus for solution preparations.
2.3. Chromatographic Conditions. The method was developed and validated by using fused silica DB-624 $(30 \mathrm{~m} \times 0.32 \mathrm{~mm} \times 1.8 \mu \mathrm{m})$ column with the flame ionization detector (FID) and the chromatographic parameters are given in Table 1. The chromatographic retention time of acetone and isopropyl alcohol is given in Table 2 .

\subsection{Preparation of Solutions}

2.4.1. Diluent Solution. A mixture of N,N-dimethylsulfoxide and water was used as diluent.

2.4.2. Blank Solution. Transfer $5 \mathrm{~mL}$ of diluent into $20 \mathrm{~mL}$ headspace and crimp cap immediately.

2.4.3. Preparation of Standard Solution (Stock). Weigh and transfer about $500 \mathrm{mg}$ of isopropyl alcohol and $500 \mathrm{mg}$ of acetone into $50 \mathrm{~mL}$ volumetric flask containing about $30 \mathrm{~mL}$ of diluent mix and make up to the mark with diluent.

2.4.4. Preparation of Standard Solution. Pipette out $5 \mathrm{~mL}$ of the above standard stock solution into $100 \mathrm{~mL}$ volumetric flask and make up to the mark with diluent. Transfer $5 \mathrm{~mL}$ of above solution into $20 \mathrm{~mL}$ headspace vials, and crimp cap immediately.

2.4.5. Preparation of Sample Solution. Open five capsules and crush the pellets using mortar pestle. Weigh and transfer $500 \mathrm{mg}$ of crushed powder into $20 \mathrm{~mL}$ headspace vial, add $5 \mathrm{~mL}$ of diluent, and crimp the cap immediately.

2.5. System Suitability Criteria. The present relative standard deviation of standard peak area for six replicate injections should not be more than 10 .

\section{Results and Discussion}

3.1. Method Development and Optimization. The analytical method development was initiated by using the Agilent 7890A coupled with G1888 network headspace sampler, fused silica DB-624 $(30 \mathrm{~m} \times 0.32 \mathrm{~mm} \times 1.8 \mu \mathrm{m})$ column with the flame ionization detector (FID), carrier gas as helium. The front injector conditions (injector temperature $140^{\circ} \mathrm{C}$, carrier gas flow $2.0 \mathrm{~mL} / \mathrm{min}$, and split ration $5: 1$ ), front detector conditions (detector temperature $260^{\circ} \mathrm{C}$, hydrogen flow $40 \mathrm{~mL} / \mathrm{minute}$, and air flow $300 \mathrm{~mL} / \mathrm{minute}$ ), oven conditions $\left(40^{\circ} \mathrm{C}\right.$ for 10 minutes and increasing the temperature to $250^{\circ} \mathrm{C}$ at the rate of $30^{\circ} \mathrm{C} /$ minute and hold for 10 minutes), headspace oven temperature $100^{\circ} \mathrm{C}$, loop temperature $105^{\circ} \mathrm{C}$, transfer line temperature $110^{\circ} \mathrm{C}$. The dimethylsulfoxide used as diluent for solution preparations. Based on the above experiment, we found the very less resolution between acetone and isopropyl alcohol. The further experiments were conducted by altering the chromatographic conditions to achieve satisfactory resolution between acetone and isopropyl alcohol. 
TABle 1: Chromatographic parameters.

\begin{tabular}{|c|c|c|c|}
\hline Column & $\begin{array}{c}\text { Fused silica DB-624 } \\
(30 \mathrm{~m} \times 0.32 \mathrm{~mm} \times 1.8 \mu \mathrm{m})\end{array}$ & Makeup gas flow & $25 \mathrm{~mL} /$ minute \\
\hline Detector & Flame ionization detector (FID) & Oven temperature & $\begin{array}{l}40^{\circ} \mathrm{C} \text { for } 10 \text { minutes and increasing the } \\
\text { temperature to } 210^{\circ} \mathrm{C} \text { at the rate of } 35^{\circ} \mathrm{C} / \text { minute } \\
\text { and kept for } 5 \text { minutes }\end{array}$ \\
\hline Mode & Constant flow & \multicolumn{2}{|r|}{ Headspace sampler condition } \\
\hline Carrier gas & Nitrogen & Oven temperature & $80^{\circ} \mathrm{C}$ \\
\hline Front Injector condition & & Loop temperature & $90^{\circ} \mathrm{C}$ \\
\hline Inject temperature & $140^{\circ} \mathrm{C}$ & $\begin{array}{l}\text { Transfer line } \\
\text { temperature }\end{array}$ & $100^{\circ} \mathrm{C}$ \\
\hline Carrier gas flow & $1.0 \mathrm{~mL} / \mathrm{min}$ & GC cycle time & 34 minutes \\
\hline Split ratio & $20: 1$ & Vial equilibration time & 20 minutes \\
\hline Injector type & Split & Pressurization time & 1.0 minutes \\
\hline Front detector condition & & Loop fill time & 0.2 minutes \\
\hline $\begin{array}{l}\text { Detector } \\
\text { temperature }\end{array}$ & $260^{\circ} \mathrm{C}$ & $\begin{array}{l}\text { Loop equilibration } \\
\text { time }\end{array}$ & 0.05 minutes \\
\hline Hydrogen flow & $30 \mathrm{~mL} /$ minute & Injection time & 1.0 minutes \\
\hline Air flow & $300 \mathrm{~mL} /$ minute & Shake & High \\
\hline
\end{tabular}

TABLE 2: Retention times of acetone and isopropyl alcohol.

\begin{tabular}{lcc}
\hline Serial Number & Impurity name & RT (about) \\
\hline 1 & Acetone & 6.8 \\
2 & Isopropyl alcohol & 7.3 \\
\hline
\end{tabular}

The further experiment was conducted by using the above experiment chromatographic parameters and by changing the front injector condition and headspace sampler condition. Based on the above experiment, we found the very less resolution between acetone and isopropyl alcohol and found the placebo peak interference was observed at the retention time of acetone. The aim is to resolve the issue of placebo peak interference, needs to modify the diluent or headspace oven temperature conditions to finalize the method conditions.

The further experiment was conducted by using the fused silica DB-624 $(30 \mathrm{~m} \times 0.32 \mathrm{~mm} \times 1.8 \mu \mathrm{m})$ column with the flame ionization detector (FID), carrier gas as nitrogen. The front injector conditions (injector temperature $140^{\circ} \mathrm{C}$, carrier gas flow $1.0 \mathrm{~mL} / \mathrm{min}$, and split ration $20: 1$ ), front detector conditions (detector temperature $260^{\circ} \mathrm{C}$, hydrogen flow $30 \mathrm{~mL} /$ minute, and air flow $300 \mathrm{~mL} /$ minute), oven conditions $\left(40^{\circ} \mathrm{C}\right.$ for 10 minutes and increasing the temperature to $210^{\circ} \mathrm{C}$ at the rate of $35^{\circ} \mathrm{C} /$ minute and hold for 5 minutes), headspace oven temperature $80^{\circ} \mathrm{C}$, loop temperature $90^{\circ} \mathrm{C}$, transfer line temperature $100^{\circ} \mathrm{C}$. The misture of $\mathrm{N}, \mathrm{N}$-dimethylsulfoxide and water used as diluent for solution preprations. Based on the above experiment, it was found that no placebo interference was observed at the retention time of acetone and isopropyl alcohol, and resolution was found satisfactory.

Based on the optimization of the trials, the abovementioned chromatographic conditions were finalized for the quantification of the acetone and isopropyl alcohol in tartaric acid-based pellets of dipyridamole modified release capsules. Hence, this method can be validated and introduced for the routine analysis.
3.2. Method Validation. The developed analytical method for quantification of the residual solvents in the tartaric acidbased pellets of dipyridamole modified release capsules was validated as per International Council for Harmonisation of Technical Requirements for Pharmaceuticals for Human Use (ICH) [15]. The validation parameters [17, 18] specificity, estimation of limit of detection (LOD), and limit of quantification (LOQ), accuracy, precision, linearity, range, ruggedness, and robustness were examined [17, 18].

3.2.1. System Suitability. To check the system suitability criteria, the solutions were prepared and injected as per the test method. All the parameters were found well within the acceptance criteria (Table 3).

3.2.2. Limit of Detection and Limit of Quantification. The limit of detection (LOD) and limit of quantification (LOQ) were established by the signal-to-noise ratio method by preparing the known concentrations of acetone and isopropyl alcohol and injected into gas chromatography headspace instrument as per the test method. The limit of detection and limit of quantification for each matrix were determined from the signal-to-noise ratio $(\mathrm{S} / \mathrm{N})$ method of $3: 1$ and $10: 1$ by injecting the standard solutions (Table 4). The LOD and LOQ were verified by analysis of spiked standard solutions predefined acceptance criteria. The percent relative standard deviation for area response found for acetone at LOD concentration is 7.1 and LOQ is 3.5 and for isopropyl alcohol at LOD concentration is 5.2 and LOQ is 3.7 .

3.2.3. Specificity. Specificity was accomplished by injecting the samples as per the test method and as a part of the specificity study. Blank, acetone, isopropyl alcohol solvent, and placebo were prepared and injected as per test method. No peak interference at the retention time of acetone and 
TABLE 3: System suitability criteria and results

\begin{tabular}{lc}
\hline Parameter & Acceptance criteria \\
\hline $\begin{array}{l}\text { The present relative standard deviation of acetone } \\
\text { peak area for six replicate injections. }\end{array}$ & $\leq 10.0$ \\
$\begin{array}{l}\text { The present relative standard deviation of isopropyl } \\
\text { alcohol peak area for six replicate injections. }\end{array}$ & $\leq 10.0$ \\
$\begin{array}{l}\text { The present relative standard deviation of acetone } \\
\text { retention time for six replicate injections. }\end{array}$ & $\leq 10.0$ \\
$\begin{array}{l}\text { The present relative standard deviation of isopropyl } \\
\text { alcohol retention time for six replicate injections. }\end{array}$ & $\leq 10.0$ \\
\hline
\end{tabular}

TABLE 4: Limit of detection and Limit of quantification.

\begin{tabular}{lcc}
\hline Name & LOD & LOQ \\
Concentration $(\mu \mathrm{g} / \mathrm{mL})$ & Concentration $(\mu \mathrm{g} / \mathrm{mL})$ \\
\hline Acetone & 3 & 7 \\
Isopropyl alcohol & 11 & 27 \\
\hline
\end{tabular}

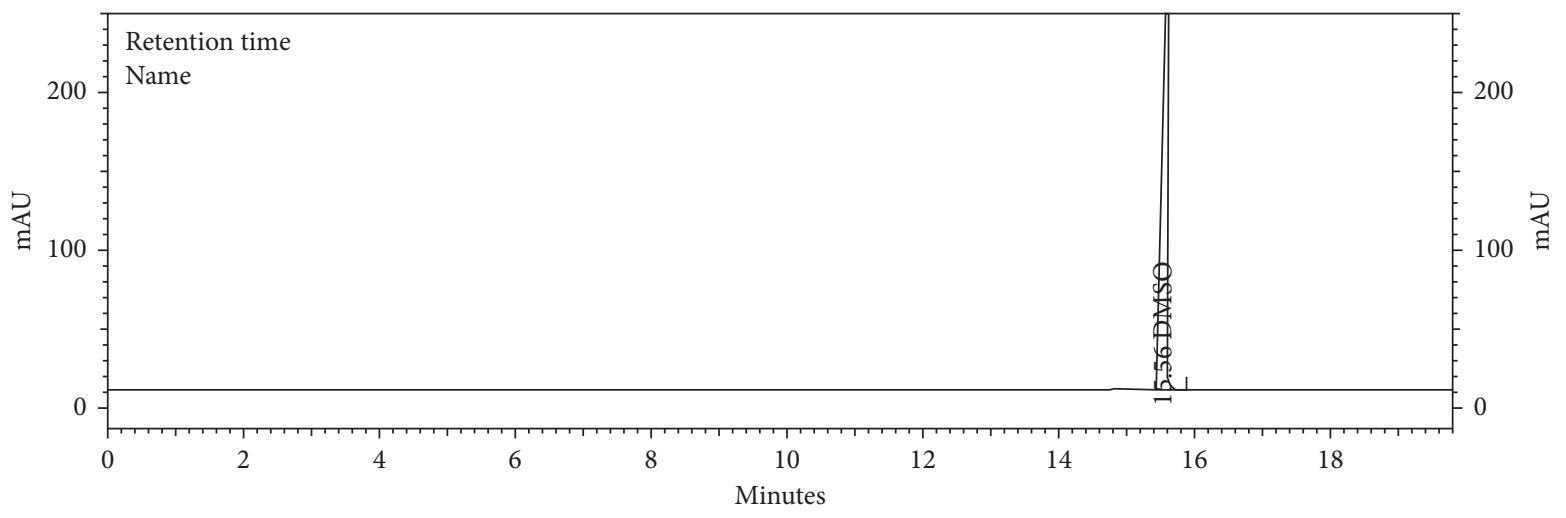

Front signal

DIPCX_RES035_0446

FIgURe 2: Typical chromatogram of blank.

isopropyl alcohol was observed. Therefore, we conclude that this method is selective and suitable for the identification and quantification of the acetone and isopropyl alcohol in the dipyridamole modified release capsules.

The chromatograms are given for the blank (Figure 2), placebo (Figure 3), acetone (Figure 4), isopropyl alcohol (Figure 5), standard (Figure 6), as-such sample (Figure 7), and spiked blend solution (Figure 8).

3.2.4. Method Precision (Repeatability). The method precision or intraassay precision was performed by preparing the six replicate test preparations $(n=6)$ of dipyridamole $200 \mathrm{mg}$ modified release capsules by spiking acetone and isopropyl alcohol specification level (Table 5 and Figure 9) analyzed as per the test method. The concentration in parts per million was calculated and found to be within the acceptance criteria. The relative standard deviations obtained for acetone were $1.0 \%$ and isopropyl alcohol $1.4 \%$. The graphs for acetone and isopropyl alcohol are shown in Figure 9.
3.2.5. Accuracy. Accuracy of the proposed analytical procedure was evaluated from the assay results of the acetone and isopropyl alcohol as per the test method. A series of sample solutions were prepared in triplicate (six replicate test preparations for LOQ and about $200 \%$ levels) by spiking the acetone and isopropyl alcohol in placebo except LOQ level in the range of about $25 \%, 50 \%, 100 \%$, and $150 \%$ of specification level and injected into HPLC system and analyzed as per the test method. The concentrations of acetone are $7.5 \mu \mathrm{g} / \mathrm{mL}$, $1300 \mu \mathrm{g} / \mathrm{mL}, 2738 \mu \mathrm{g} / \mathrm{mL}, 5050 \mu \mathrm{g} / \mathrm{mL}$, and $7694 \mu \mathrm{g} / \mathrm{mL}$ and of isopropyl alcohol are $28 \mu \mathrm{g} / \mathrm{mL}, 1304 \mu \mathrm{g} / \mathrm{mL}, 2745 \mu \mathrm{g} / \mathrm{mL}$, $5063 \mu \mathrm{g} / \mathrm{mL}$, and $7715 \mu \mathrm{g} / \mathrm{mL}$. Individual $\%$ recovery, mean $\%$ recovery, \% RSD, and squared correlation coefficient for linearity of the test method were calculated, and the results were found to be within the acceptance criteria (Table 6). The linearity graphs from accuracy results for acetone and isopropyl alcohol are shown in Figures 10 and 11, respectively.

3.2.6. Linearity. The linearity was studied by analyzing the standard solutions. A series of solutions of acetone and 


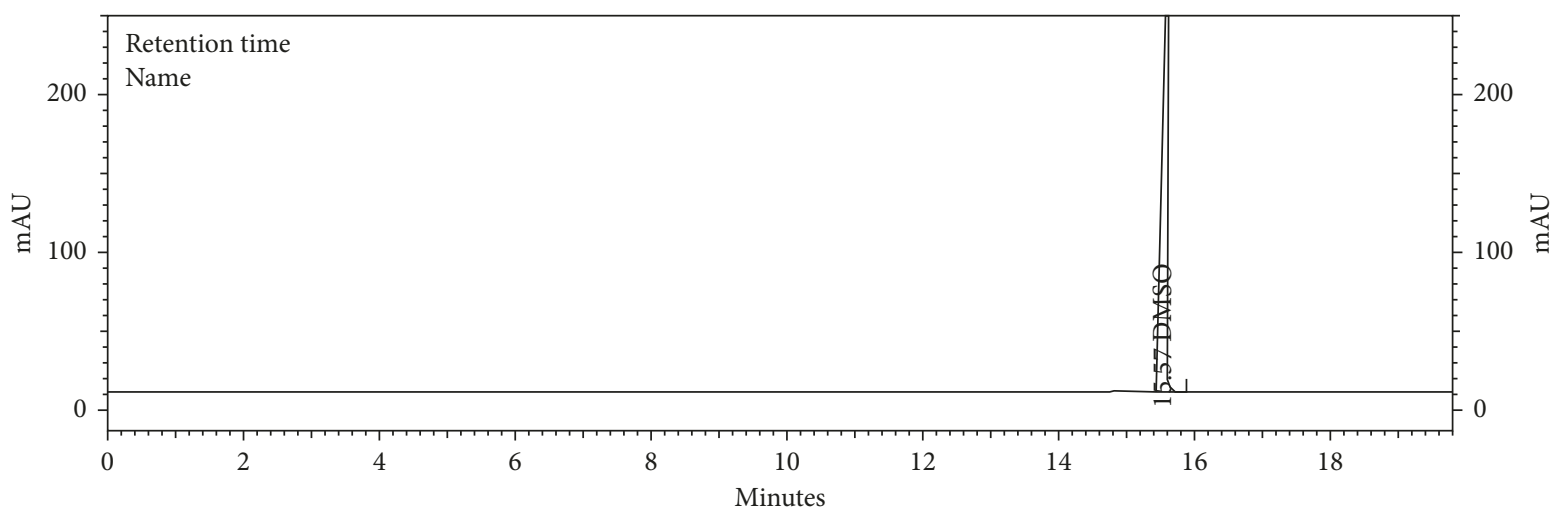

Front signal

Placebo

DIPCX_RES035_0703

Figure 3: Typical chromatogram of placebo.

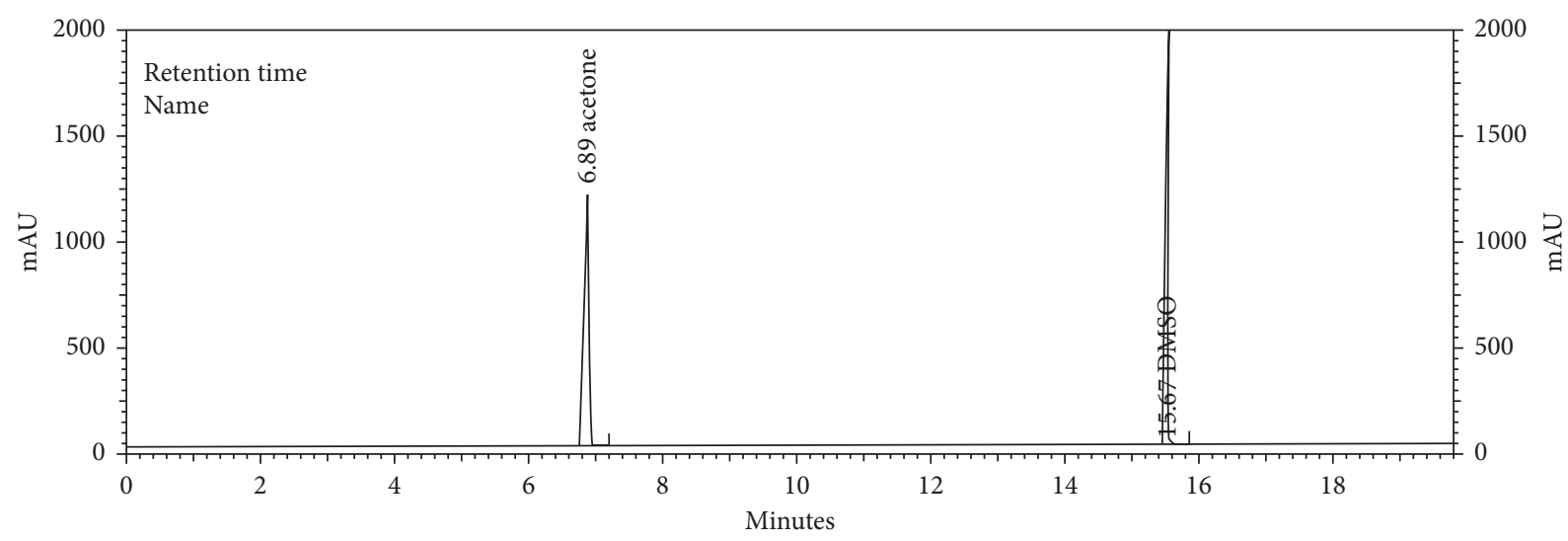

Front signal

DIPCX_RES035_0454

FIgURE 4: Typical chromatogram of acetone.

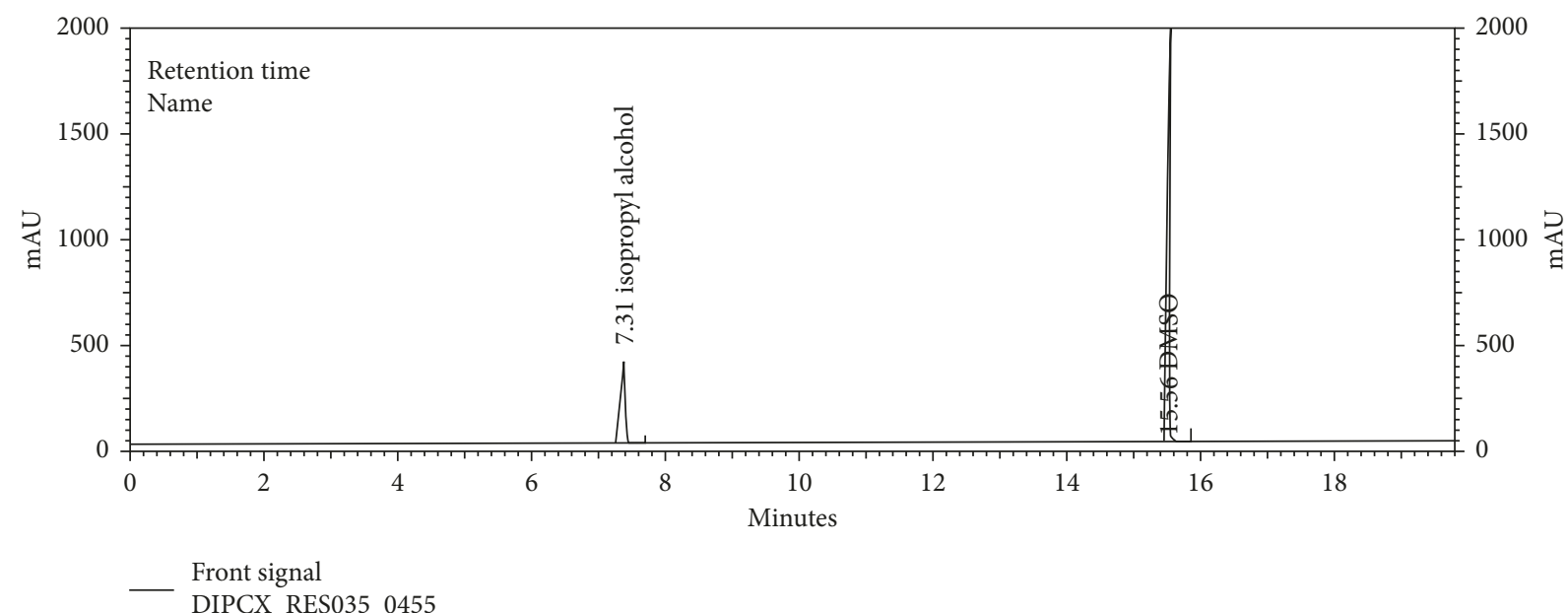

FIGURE 5: Typical chromatogram of isopropyl alcohol.

isopropyl alcohol solutions were prepared in the range of LOQ to about $150 \%$ of specification level and injected into the HPLC system. Linearity of detector response was established by plotting a graph between concentration versus response of acetone and isopropyl alcohol peaks. The detector response was found to be linear from about LOQ to 


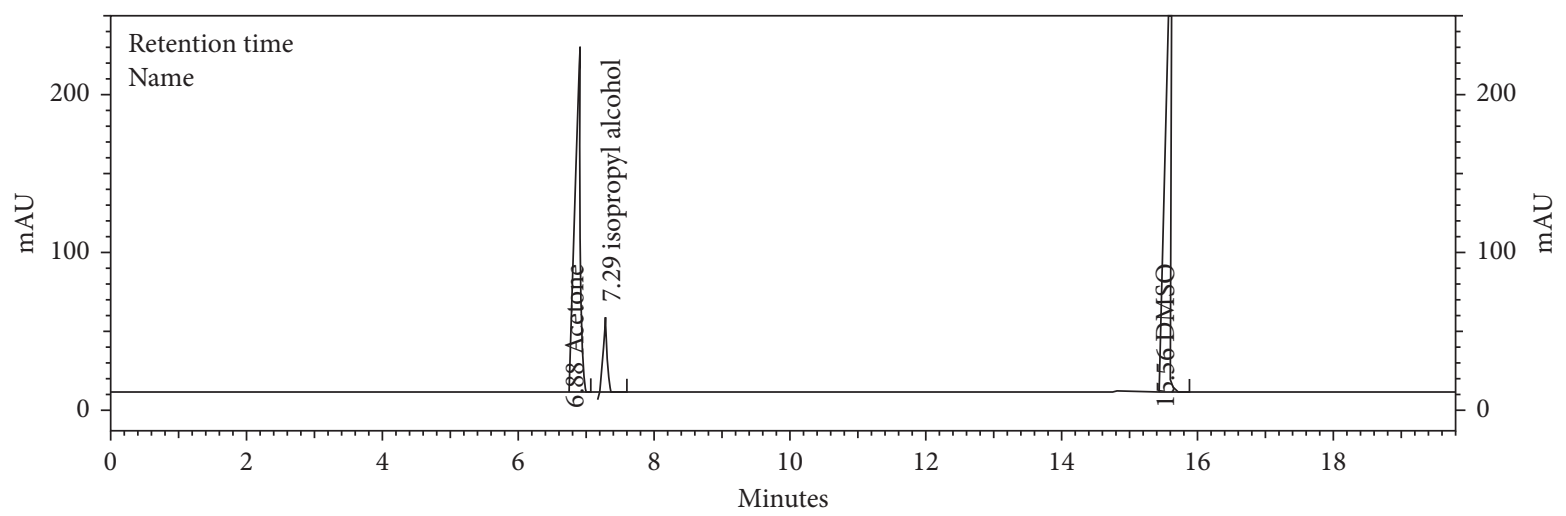

Front signal

DIPCX_RES035_0447

Figure 6: Typical chromatogram of standard solution.

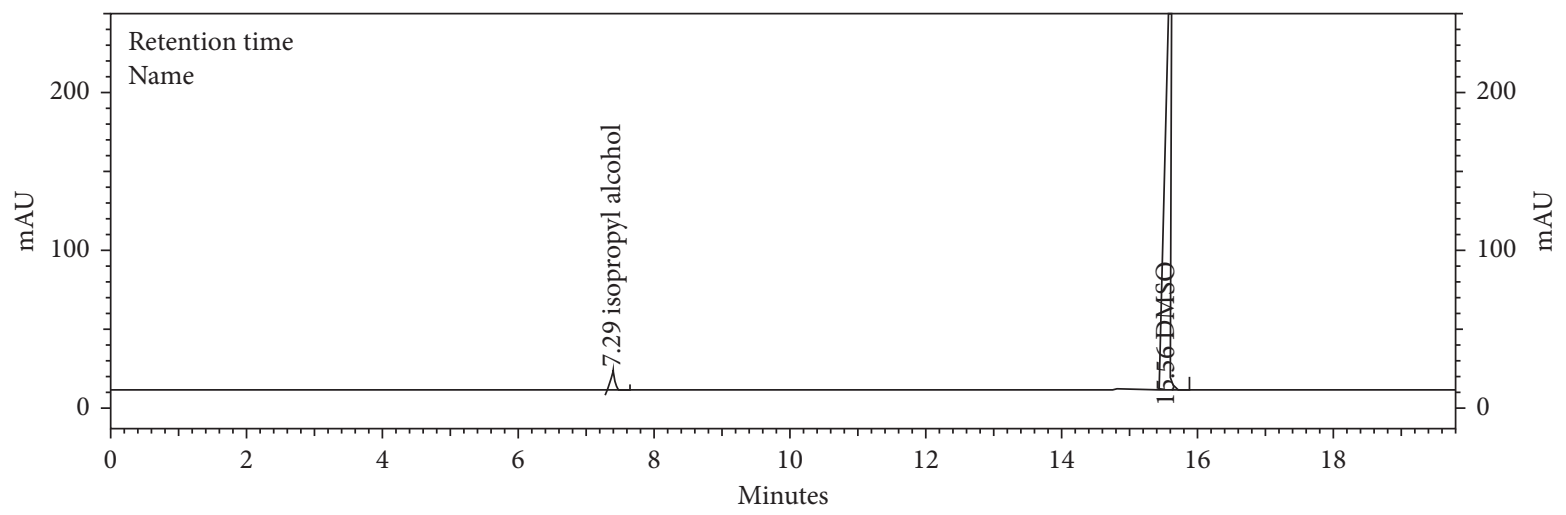

Front signal

DIPCX_RES035_0456

FIgURE 7: Typical chromatogram of as-such sample.

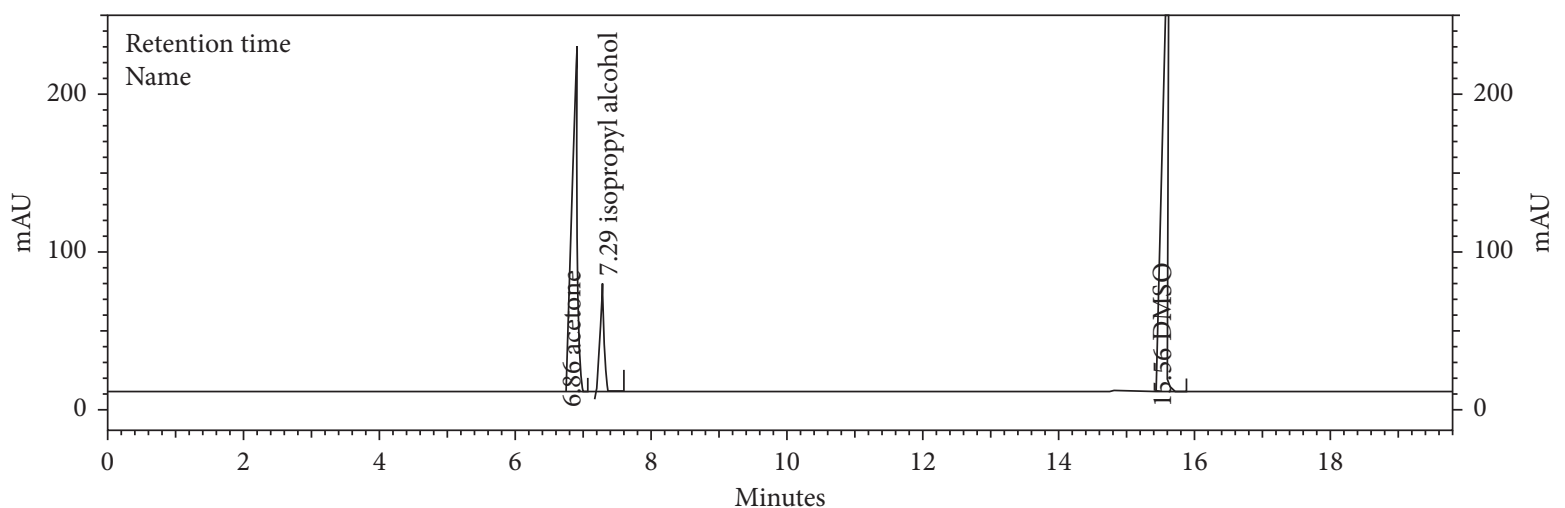

Front signal

DIPCX_RES035_0457

Figure 8: Typical chromatogram of spiked sample.

$150 \%$ of specification level and injected into HPLC system and analyzed as per the test method. The concentrations of acetone are $7 \mu \mathrm{g} / \mathrm{mL}, 1260 \mu \mathrm{g} / \mathrm{mL}, 3024 \mu \mathrm{g} / \mathrm{mL}$, $5040 \mu \mathrm{g} / \mathrm{mL}$, and $7560 \mu \mathrm{g} / \mathrm{mL}$ and of isopropyl alcohol are
$27 \mu \mathrm{g} / \mathrm{mL}, \quad 1261 \mu \mathrm{g} / \mathrm{mL}, \quad 3027 \mu \mathrm{g} / \mathrm{mL}, \quad 5045 \mu \mathrm{g} / \mathrm{mL}, \quad$ and $7567 \mu \mathrm{g} / \mathrm{mL}$.

The square of correlation coefficient, slope, and \% $y$-intercept at $100 \%$ level, intercept, and residual sum of 
TABLE 5: Method precision data for spiked sample.

\begin{tabular}{lcc}
\hline Sample number & Acetone & Isopropyl alcohol \\
\hline 1 & 5242 & 6391 \\
2 & 5346 & 6538 \\
3 & 5369 & 6542 \\
4 & 5289 & 6469 \\
5 & 5240 & 6315 \\
6 & 5281 & 6413 \\
Mean & 5294 & 6445 \\
\%SD & 1.0 & 1.4 \\
\hline
\end{tabular}

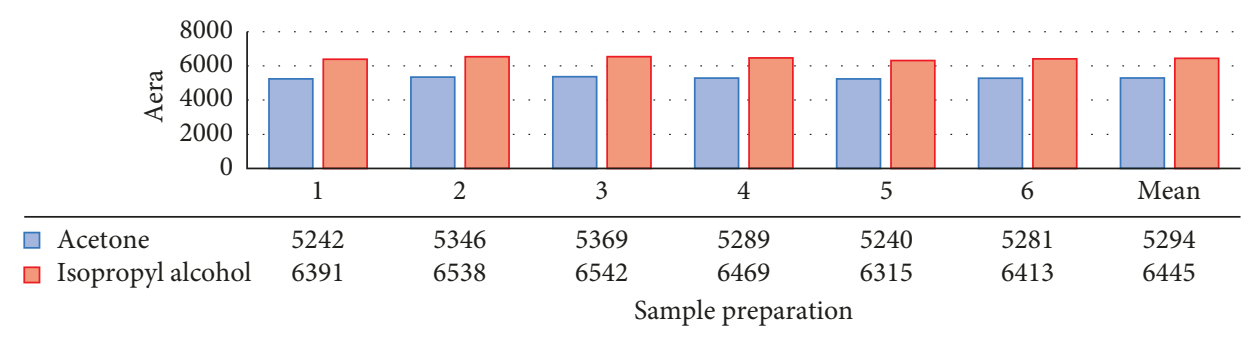

Figure 9: Method precision.

Table 6: Accuracy data of acetone and isopropyl alcohol.

Spike level

\begin{tabular}{lccc} 
& & Acetone & Isopropyl alcohol \\
\hline \multirow{2}{*}{ Level-1 LOQ } & Mean & 108.2 & 109.9 \\
& \% RSD & 2.6 & 2.0 \\
Level-2 LOQ & Mean & 94.2 & 106.8 \\
Level-3 LOQ & \% RSD & 0.2 & 1.6 \\
& Mean & 94.7 & 104.9 \\
Level-4 LOQ & \% RSD & 1.5 & 1.7 \\
& Mean & 101.2 & 110.1 \\
Level-5 LOQ & \% RSD & 0.6 & 0.1 \\
& Mean & 101.3 & 108.1 \\
\end{tabular}

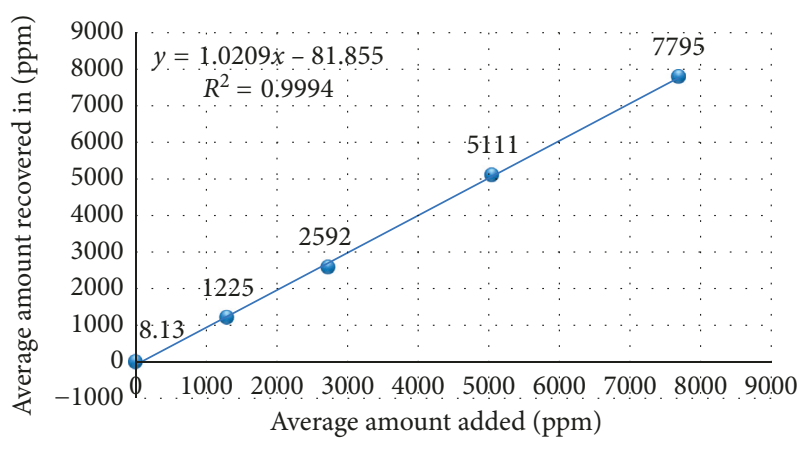

FiguRE 10: Linearity plot for acetone from accuracy results.

squares were calculated, and the results were found to be within the acceptance criteria (Table 7). The linearity graphs from accuracy results for acetone and isopropyl alcohol are shown in Figures 12 and 13, respectively.

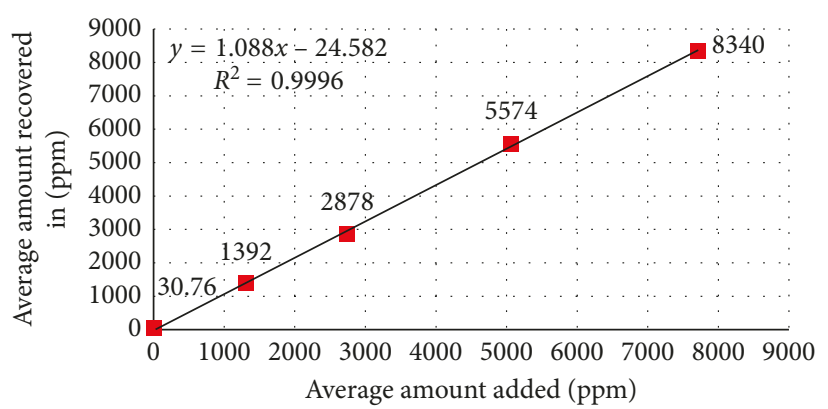

FIgURE 11: Linearity plot for isopropyl alcohol from accuracy results.

3.2.7. Ruggedness (Intermediate Precision). Intermediate precision was performed by preparing the six replicate test preparations $(n=6)$ of dipyridamole $200 \mathrm{mg}$ 
TABLE 7: Linearity data of acetone and isopropyl alcohol.

\begin{tabular}{lcc}
\hline Description & \multicolumn{2}{c}{$\begin{array}{c}\text { Dipyridamole and known impurities } \\
\text { Isopropyl alcohol }\end{array}$} \\
\hline Square of correlation coefficient $\left(R^{2}\right)$ & Acetone & 0.997 \\
Slope & 1385.9 & 357.7 \\
$Y$-intercept & $100,186.4$ & $39,555.8$ \\
$\% Y$-intercept & 1.4 & 2.1 \\
\hline
\end{tabular}

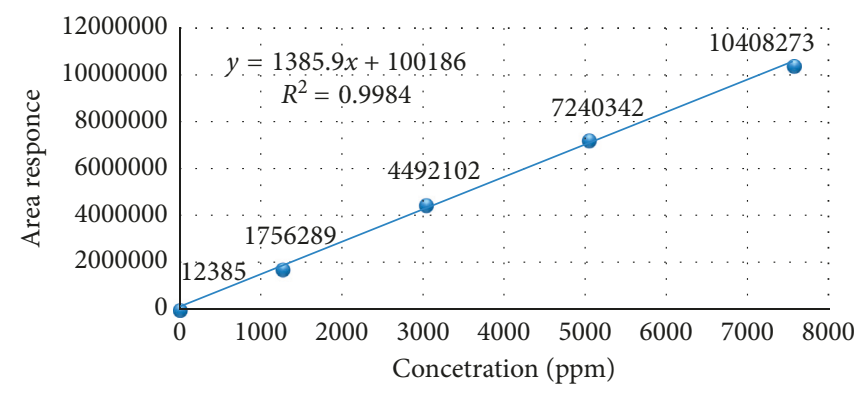

Figure 12: Linearity plot for acetone.

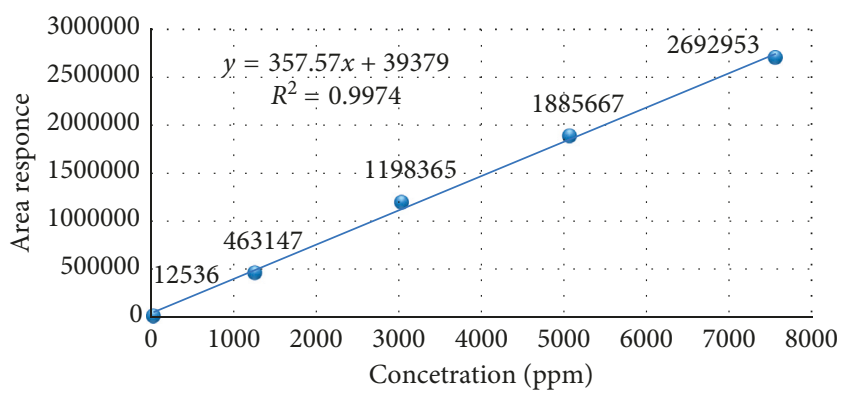

FIGURE 13: Linearity plot for isopropyl alcohol.

modified release capsules by spiking acetone and isopropyl alcohol at specification level and analyzed as per the test method by using different Headspace gas chromatography system, different column of same make by different analyst on different day. The concentration in parts per million was calculated and found to be within the acceptance criteria. The overall concentration in parts per million for replicate preparations $(n=12)$ of method precision and intermediate precision was calculated and found to be within the acceptance criteria (Table 8). The relative standard deviations obtained for acetone was $1.4 \%$ and isopropyl alcohol was $3.1 \%$.

3.2.8. Solution Stability. The solution stability of acetone and isopropyl alcohol was determined by keeping sample solution and standard solutions at room temperature for 1 day and 2 day and measured against freshly prepared standard solution. The standard solution and sample solutions were found stable for 2 days at room temperature.
TABLE 8: Ruggedness data.

\begin{tabular}{lcc}
\hline Impurity & $\begin{array}{c}\text { \% RSD for six individual } \\
\text { preparation }\end{array}$ & $\begin{array}{c}\text { The overall \% RSD } \\
(n=12)\end{array}$ \\
\hline $\begin{array}{l}\text { Acetone } \\
\begin{array}{l}\text { Isopropyl } \\
\text { alcohol }\end{array}\end{array}$ & 0.6 & 1.4 \\
\hline
\end{tabular}

3.2.9. Robustness. Robustness of the proposed method was performed by keeping the chromatographic conditions constant with the following deliberate variations:

(i) Change in carrier gas flow rate

(ii) Change in column oven temperature

(iii) Change in headspace sampler vial equilibration time

(iv) Change in headspace vial oven temperature

The standard solution was injected six times in replicate for each abovementioned change. The system suitability parameters like \% relative standard deviation for area response and \% relative standard deviation for retention time 
TABle 9: Robustness data.

\begin{tabular}{|c|c|c|c|c|}
\hline \multirow[t]{2}{*}{ Parameter variation } & \multicolumn{2}{|c|}{$\begin{array}{l}\text { The present relative standard } \\
\text { deviation of peak area for six } \\
\text { replicate injections should not more } \\
\text { than } 10.0\end{array}$} & \multicolumn{2}{|c|}{$\begin{array}{l}\text { The present relative standard } \\
\text { deviation of retention time for six } \\
\text { replicate injections should not more } \\
\text { than } 10.0\end{array}$} \\
\hline & Acetone & Isopropyl alcohol & Acetone & Isopropyl alcohol \\
\hline Flow $0.8 \mathrm{~mL} / \mathrm{min}$ & 0.4 & 0.6 & 0.0 & 0.0 \\
\hline Flow $1.2 \mathrm{~mL} / \mathrm{min}$ & 0.5 & 0.7 & 0.1 & 0.0 \\
\hline Column oven temperature $35^{\circ} \mathrm{C}$ & 0.3 & 1.0 & 0.0 & 0.0 \\
\hline Column oven temperature $45^{\circ} \mathrm{C}$ & 0.4 & 0.6 & 0.0 & 0.0 \\
\hline Headspace vial equilibration time $15 \mathrm{~min}$ & 1.2 & 3.1 & 0.0 & 0.0 \\
\hline Headspace vial equilibration time $25 \mathrm{~min}$ & 0.2 & 0.7 & 0.0 & 0.1 \\
\hline Headspace vial oven temperature $75^{\circ} \mathrm{C}$ & 0.5 & 0.8 & 0.0 & 0.1 \\
\hline Headspace vial oven temperature $85^{\circ} \mathrm{C}$ & 0.2 & 0.4 & 0.0 & 0.0 \\
\hline
\end{tabular}

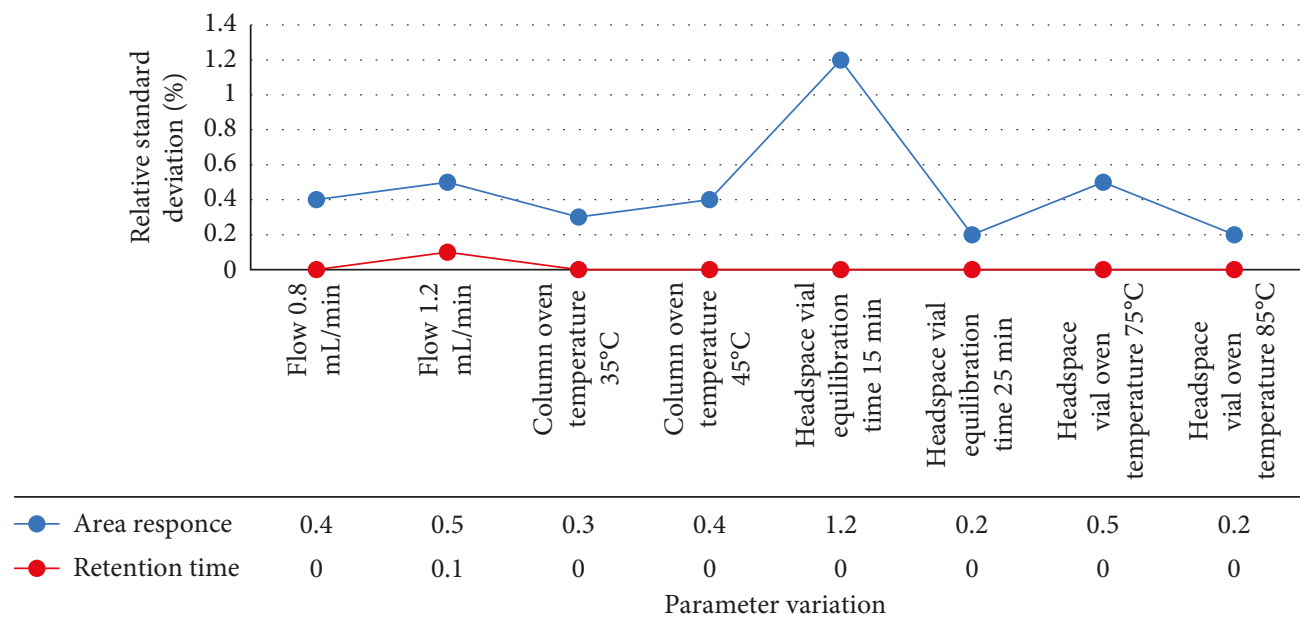

FIGURE 14: Robustness data for acetone.

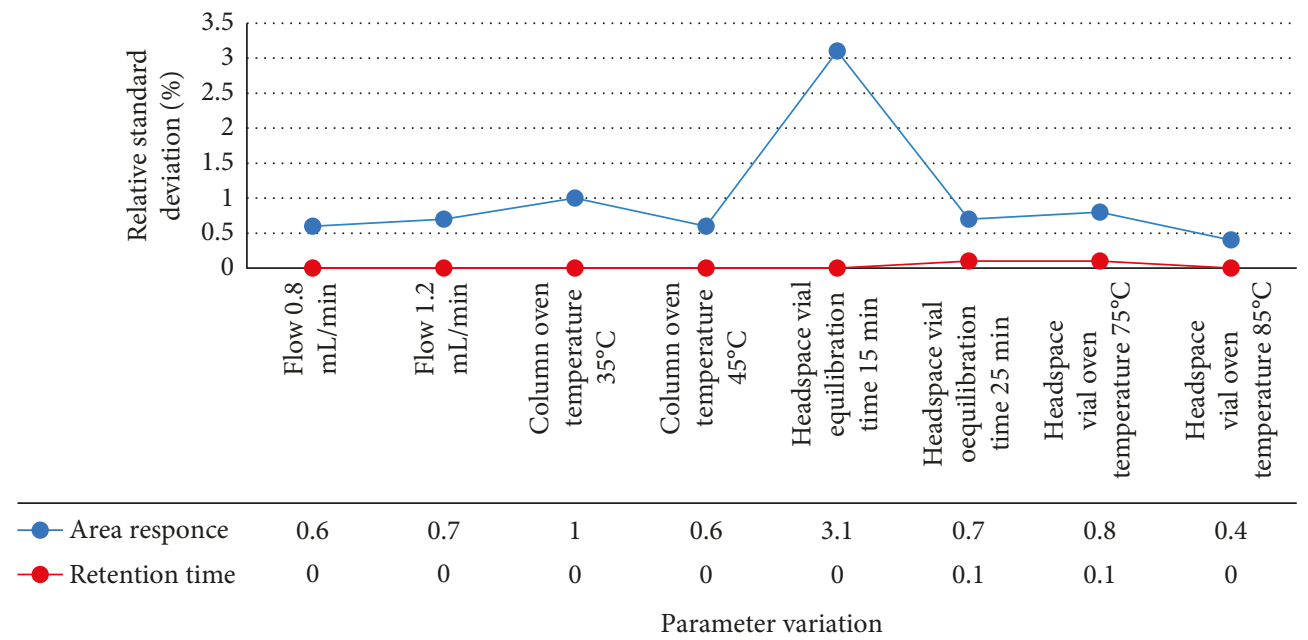

FIgURE 15: Robustness data for isopropyl alcohol.

were recorded for acetone and isopropyl alcohol and found well within the acceptance criteria. The results are given in Table 9, and the graphs for acetone and isopropyl alcohol are shown in Figures 14 and 15, respectively.
3.2.10. Application of the Proposed Method. The developed analytical method was applied to the analysis of real samples from the manufacturing unit. All the analytical validation parameters could be confirmed, and the method was proven 
to be suitable for routine analysis regarding rapid and accurate results.

\section{Conclusions}

A simple, sensitive, accurate, robust headspace gas chromatographic method was developed for the quantitative determination of residual solvents in tartaric acid-based pellets of dipyridamole modified release capsules. The proposed method was validated and found to be precise, accurate, linear, robust, and rugged, and all the validation parameter results were found satisfactory. The described method is suitable for routine analysis of production samples at laboratories.

\section{Conflicts of Interest}

The authors declare that there are no conflicts of interest regarding the publication of this paper.

\section{Acknowledgments}

The authors wish to thank the management of Bluefish Pharmaceuticals Private Limited for supporting and encouragement.

\section{References}

[1] V. Karuppiah, N. Kannappan, and R. Manavalan, "In-vitro and in-vivo dissolution of dipyridamole extended release capsules," International Journal of Pharmaceutical Sciences Review and Research, vol. 13, no. 1, 2012.

[2] S. U. Ahmed, P. R. Katikaneni, and Y. Zu, "Pharmaceutical capsules comprising extended release dipyridamole pellets," WO2009097156A1, 2009.

[3] Persantin Retard $200 \mathrm{mg}$, Summary of Product Characteristics (SmPC), The electronic Medicines Compendium (emc), https://www.medicines.org.uk/emc/product/897/smpc.

[4] S. S. Raju, U. Vidyamani, P. Jayapal, and P. Naga Raju, "Development and validation of a head space gas chromatographic method for the determination of ethylene oxide content in dipyridamole API," World Journal of Pharmaceutical Research, vol. 4, no. 11, pp. 1127-1139.

[5] A. R. Zoest, J. E. Watson, C. T. Hung, and S. A. Wanwimolruk, "Rapid isocratic HPLC assay for dipyridamole using a microbore column technique," Journal of Liquid Chromatography, vol. 14, no. 10, pp. 1967-1975, 1991.

[6] A. Sreedhara Rao, M. Krishnaji Rao, A. S. Dadichand, A. M. L. Punna Rao, and B. Balaswami, "Development and validation of RP-HPLC method for assay of dipyridamole in formulations," vol. 8, no. 5, pp. 256-259, 2016.

[7] J. H. Bridle and M. T. Brimble, "A stability indicating method for dipyridamole," Informa Healthcare Drug Development and Industrial Pharmacy, vol. 19, no. 3, pp. 371-381, 1993.

[8] J. Zhang, R. B. Miller, and R. Jacobus, "Development and validation of a stability-indicating HPLC method for the determination of degradation products in dipyridamole injection," Chromatographia, vol. 44, no. 5-6, pp. 247-252, 1997.

[9] B. K. Vagela, S. Singh Rao, and P. Sunil Reddy, "Development and validation of a stability-indicating RP-LC method for the estimation of process related impurities and degradation products of dipyridamole retard capsules," International
Journal of Pharmacy and Pharmaceutical Sciences, vol. 4, no. 1, 2012.

[10] K. Prakash, R. Rao Kalakuntla, and J. Reddy Sama, "Rapid and simultaneous determination of aspirin and dipyridamole in pharmaceutical formulations by reversed- phase high performance liquid chromatography (RP-HPLC) method," African Journal of Pharmacy and Pharmacology, vol. 5, no. 2, pp. 244-251, 2011.

[11] A. P. Rajput and C. M. Sonanis, "Development and validation of a rapid RP-UPLC method for the determination of aspirin and dipyridamole in combined capsule formulation," International Journal of Pharmacy and Pharmaceutical Sciences, vol. 3, no. 2, 2011.

[12] H. H. Hammud, F. A. Yazbib El, M. E. Mahrousc, G. M. Sonjib, and N. M. Sonjib, "Stability-indicating spectro fluorimetric and RP-HPLC methods for the determination of aspirin and dipyridamole in their combination," Open Spectroscopy Journal, vol. 2, no. 1, pp. 19-28, 2008.

[13] Z. Kopitar and H. Weisenberger, "Specific binding of dipyridamol on human serum protein. Isolation, identification and characterization as alpha-1-acidic glycoprotein," Arzneimittel-Forschung, vol. 21, no. 6, pp. 859-862, 1971.

[14] D. B. Bandarabadi, M. P. Hamedani, M. Amini, and A. Shafiee, "High performance liquid chromatographic method for determination of dipyridamole in human plasma," DARU Journal of Pharmaceutical Sciences, vol. 7, no. 2, 1999.

[15] T. Qin, F. Qin, N. Li, S. Lu, W. Liu, and F. Li, "Quantitative determination of dipyridamole in human plasma by highperformance liquid chromatography-tandem mass spectrometry and its application to a pharmacokinetic study," Biomedical Chromatography, vol. 24, no. 3, pp. 268-273, 2010.

[16] ICH Q2 (R1), "Validation of analytical procedures: text and methodology", Harmonised Tripartite Guideline, in Proceedings of the International Conference on Harmonisation of Technical Requirements for Registration of Pharmaceuticals for Human Use, Chicago, USA, 2005.

[17] P. S. Reddy, V. S. K. Jagarlapudi, and C. B. Sekharan, "Determination of edoxaban in bulk and in tablet dosage form by stability indicating high-performance liquid chromatography," Pharmaceutical Sciences, vol. 22, no. 1, pp. 35-41, 2016.

[18] V. K. Nekkala, J. S. Kumar, D. Ramachandran, and G. Ramanaiah, "Development and validation of stability indicating RP-LC method for estimation of calcium dobesilate in pharmaceutical formulations," Der Pharmacia Lettre, vol. 8, no. 11, pp. 236-242, 2016. 

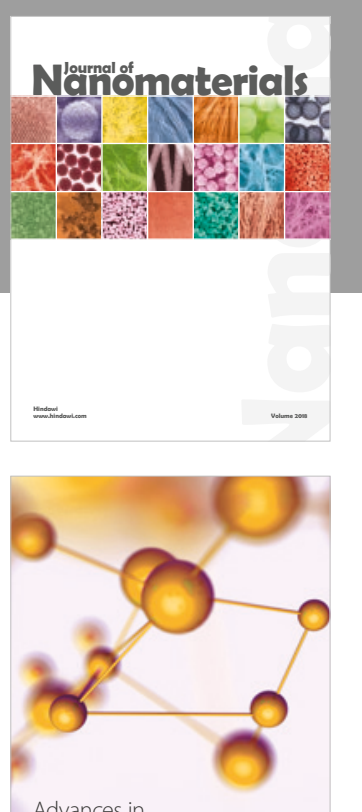

Physical Chemistry
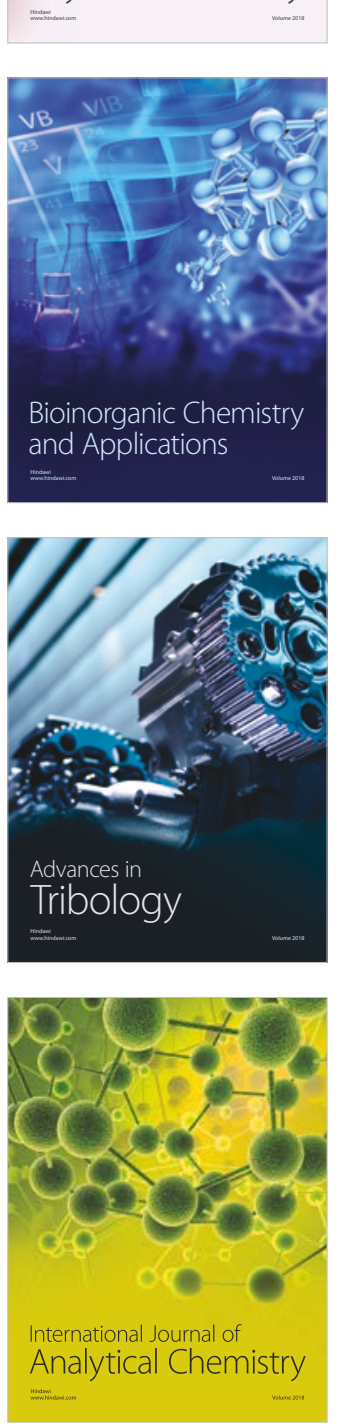

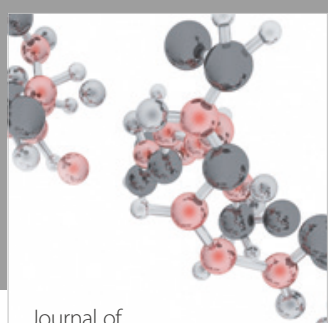

Analytical Methods

in Chemistry

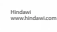

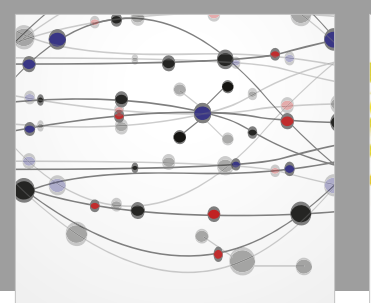

The Scientific World Journal

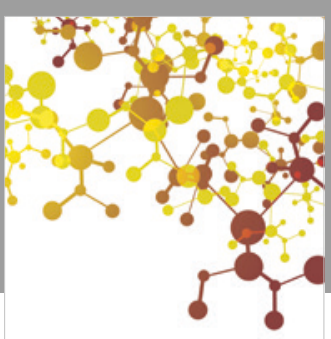

Journal of

Applied Chemistry
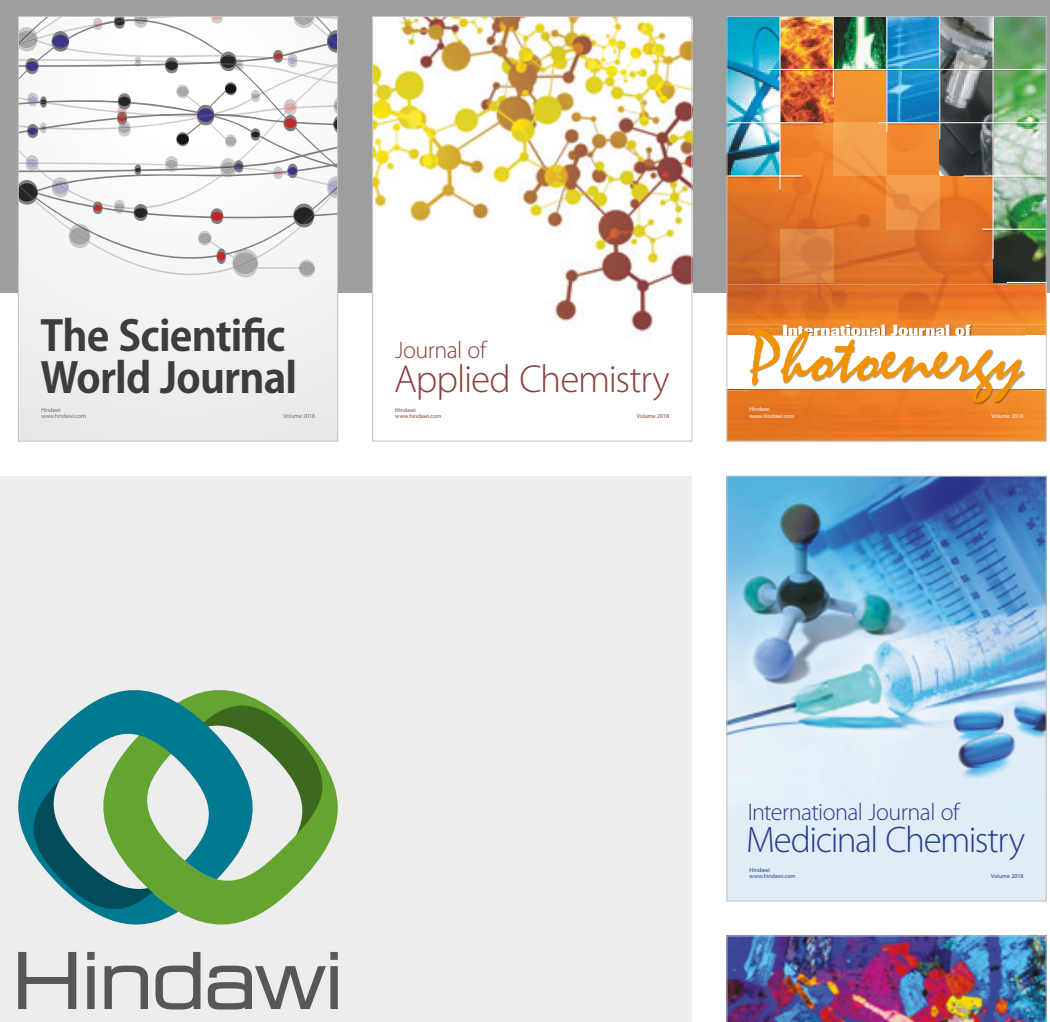

Submit your manuscripts at

www.hindawi.com
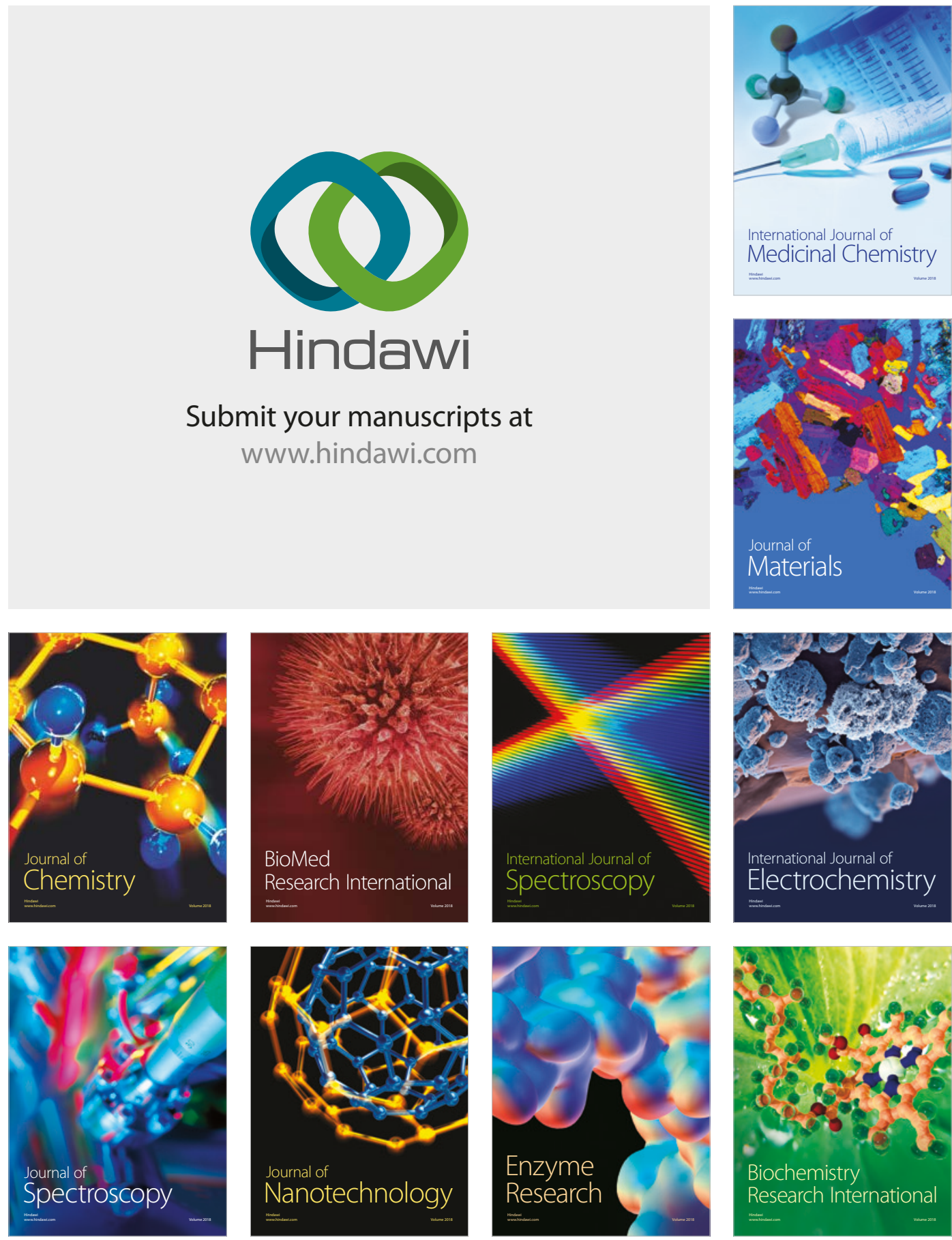
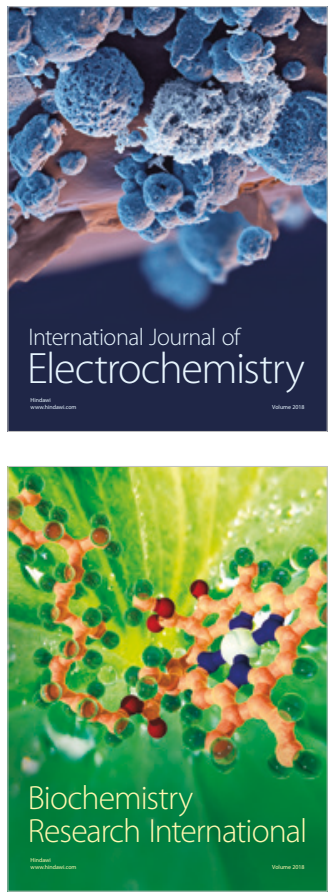